\title{
A Comparison of the Financial Characteristics of German and French Manufacturing Firms
}

\author{
Ilhan Meric (Corresponding Author) \\ College of Business Administration, Rider University \\ Lawrenceville, New Jersey 08648, USA \\ Tel: 1-609-895-5537Ｅ-mail: Meric@rider.edu \\ Kathleen Dunne \\ College of Business Administration, Rider University \\ Lawrenceville, New Jersey 08648, USA \\ Tel: 1-609-895-5540Ｅ-mail: Dunne@rider.edu
}

Wayne Smeltz

College of Business Administration, Rider University

Lawrenceville, New Jersey 08648, USA

Tel: 1-609-466-0509Ｅ-mail: Smeltz@rider.edu

Gulser Meric

Rohrer College of Business, Rowan University

Glassboro, New Jersey 08028, USA

Tel: 1-896-256-4203Ｅ-mail: Meric@rowan.edu

Received: November 13, 2012

Accepted: December 13, 2012 Online Published: December 23, 2012

doi:10.5430/afr.v2n1p32

URL: http://dx.doi.org/10.5430/afr.v2n1p32

\begin{abstract}
Comparing the financial characteristics of different groups of firms with financial ratios has been a popular methodology in finance. In this paper, we compare the financial characteristics of German and French manufacturing firms with the MANOVA (multivariate analysis of variance) statistical technique. Germany and France are members of the European Union and they have fully integrated economies with a common currency and yet, we find that financial characteristics of German and French manufacturing firms are significantly different. German manufacturing firms have significantly higher liquidity, asset turnover, and equity ratios compared with French manufacturing firms. Despite a high level of economic integration, German and French manufacturing firms appear to preserve their deep-rooted country business traditions. German manufacturing firms lower their technical insolvency risk by maintaining a significantly higher level of liquidity compared with French manufacturing firms. German manufacturing firms also reduce their bankruptcy risk by using more equity financing and less debt financing compared with their French counterparts. The profitability and sales growth ratios of manufacturing firms in the two countries are not significantly different. Although asset turnover ratios are higher in German manufacturing firms than in French manufacturing firms, French firms are able to boost their return on equity to the level in German manufacturing firms by using more debt financing and financial leverage.
\end{abstract}

Keywords: Financial characteristics, German and French manufacturing firms, MANOVA (multivariate analysis of variance) 


\section{Introduction}

\subsection{Motivation for the study}

Although a number of studies have compared the financial characteristics of firms in different countries, the effect of economic integration on the financial characteristics of manufacturing firms has not been studied sufficiently. Empirical studies show that free competition, the removal of barriers to trade, and the free cross-border flow of capital increase economic integration between countries, and firms with integrated economies tend to have similar financial characteristics (see: Stulz, 1981; Gultekin et al., 1989; Meric et al., 2007). France and Germany are members of the EU since its inception in 1958 and they have integrated economies with a common currency. Many countries have joined the EU at a later date and these countries may not yet have fully integrated economies with the other EU countries. Therefore, we do not include all EU countries in our study and we focus only on Germany and France. If the financial characteristics of firms in different countries become similar with economic integration, we should be able to see that by comparing German and French firms. In this paper, we test the hypothesis that German and French firms have similar financial characteristics.

\subsection{European Union}

The European Union (EU) was created during the aftermath of the Second World War. The first steps initiated were to foster economic cooperation: the idea "being that countries that trade with one another become economically interdependent and so more likely to avoid conflict" (European Union website). This cooperation resulted in the creation of the European Economic Community (EEC), in 1958, comprised of six countries: Belgium, Germany, France, Italy, Luxembourg and the Netherlands.

What began as a purely economic union evolved into an organization spanning all policy areas from development aid to environment. A name change from the EEC to the European Union (the EU) in 1993 reflected this change. Also during this period union membership expanded first slowly then more quickly when Eastern European countries became more democratic and capitalistic. This expansion has brought its current membership to 27 countries with a combined population of over 500 million boasting a GDP of $\$ 17$ trillion dollars or $20 \%$ of the world's GDP. The primary sector is service accounting for $71 \%$ of GDP, followed by industrial $25 \%$ and agriculture roughly $2 \%$. Of the 500 largest world businesses, 161 have their headquarters in the EU.

The EU has delivered half a century of peace, stability, and prosperity in Europe, helped raise living standards, and launched a single European currency. Thanks to the abolition of border controls between EU countries, people and goods can travel freely throughout most of the continent. The single market is the EU's main economic engine, enabling most goods, services, money and people to move freely. Another economic goal of the formation of EU is the free movement of capital that allows citizens to make unfettered stock and property purchases across EU member countries (Wikipedia website).

EU is based on the rule of law. This means that everything that it does is founded on treaties, voluntarily and democratically agreed by all member countries. These binding agreements set out the EU's goals in its many areas of activity. One such activity is the creation of the Competition Committee which has made it difficult for mergers and acquisitions that are seen to restrict market competitiveness.

While the EU has created a single currency, ten countries retain their own currency. The establishment of a single currency was an early EU priority but was not achieved until 1999. The European Central Bank was established to run monetary policy for the EU with its mandate being price stability. Price stability takes on a somewhat different connotation within the EU framework as there is greater emphasis on setting prices for individual goods and services and less on setting cross national monetary policy. The effectiveness of the ECB has been called into question given the recent banking and debt problems of many member countries. Many believe the ECB should be more autonomous from governmental influence and be allowed to be more decisive in economic and monetary policy making.

These series of problems underscore a basic vulnerability of the EU which is the significantly different economic conditions of member countries. Per capita income for the EU is around $\$ 34,000$ with a range of $\$ 15,700$ for regions of East Europe to $\$ 97,000$ for London environs. The most visible of different conditions are illustrated by the plight of Greece, Portugal and Spain who have had to seek bailouts (known as adjustment programs) and in return have had to agree to unpopular nationwide austerity programs. The source of the bailout funds is primarily Germany with France providing some support. Many EU country economies are in or are approaching recessionary condition while Germany continues to grow albeit at a slowing rate. 
While the EU and its effort to achieve economic integration has had its share of recent difficulties it remains intact and has been acknowledged to be the most advanced form of regional international economic integration achieved to date. The best evidence of accomplishment is the recent awarding of a Nobel Prize to the EU.

\subsection{Harmonization of Financial Reporting Standards in the European Union}

Members of the European Union adopted International Financial Reporting Standards (IFRS) in 2005 for all consolidated financial statements of publicly traded companies for member nations. The harmonization of accounting standards across countries was expected to increase accounting quality as well as transparency and comparability of published financial statements (Böcking et al., 2012). This move is one in a series of changes to achieve full economic integration across the European community. However, the effects of harmonization of accounting standards are not clear.

Surprisingly, although IFRS was mandatory for consolidated financial statements of publicly traded companies in the EU in 2005, Pownall and Wieczynska (2012) report that by 2009 the number of companies using accounting standards other than IFRS was approximately $17 \%$ with $42 \%$ of this group filing fully consolidated financial statements. Furthermore, the regulation and enforcement of compliance with IFRS differs across countries. Preiato et al. (2012) show mixed results for the relationship between benefits of IFRS adoption and level of enforcement. Hail et al. (2010) provides an in depth analysis of factors that affect harmonization of accounting standards including institutional, political, legal, and regulatory considerations.

Narktabtee and Patpanichchot (2011) empirically examine the role of country and firm level factors on the impact of the adoption of IFRS on value relevance of earnings and book value of equity. They use an index developed by La Porta et al. (1998) to measure investor protection at the country-level and several firm characteristics (size, volatility of sales and cash flow from operations, and frequency of negative earnings) to measure the use of management discretion. France is classified as having high investor protection and Germany is classified as having low investor protection. Furthermore, differences exist between the use of managerial discretion in accounting numbers with France having 34 companies with high managerial discretion and 51 companies with low managerial discretion compared to German firms with 24 high and 9 low managerial discretion firms. Narktabtee and Patpanichchot (2011) examine a sample of firms from 1999 to 2007 so that they may compare the pre and post effects of IFRS adoption in 2005. The results indicate that for the entire sample there is an improvement in earnings quality after the adoption of IFRS. However, when analyzing the subgroups earnings quality improves for companies with high investor protection and low ability for management discretion with no significant improvement in value relevance for the other two subgroups. Therefore, the evidence suggests that the adoption of IFRS is not sufficient to improve quality of earnings.

In summary, some would argue that the financial ratios across countries for companies in similar industries within the EU would be similar after the adoption of IFRS. However, others contend that other factors such as country specific variables may cause the financial measures to remain significantly different after 2005 .

\section{Literature Review}

Comparing the financial characteristics of different groups of firms has long been a popular methodology in finance. Altman (1968), Beaver (1968), Deakin (1972), Moyer (1977), Edmister (1972), and Dambolena and Khoury (1980) predict bankruptcy by comparing the financial characteristics of bankrupt firms before they went bankrupt and healthy firms that did not go bankrupt. Stevens (1973), Belkaoui (1978), Rege (1984), and Meric et al. (1991) identifythe financial characteristics of firms that have been corporate takeover targets by comparing them with firms that have not been targets in corporate takeovers. Hutchinson et al. (1988) and Meric and Meric (1992) identify the financial characteristics of firms which achieve stock market quotation by comparing them with firms without stock market quotation. G. Meric et al. (2000) compare the financial characteristics of Japanese kieretsu-affiliated and independent firms to identify the financial characteristics of kieretsu-affiliated firms.

A number of studies compare the financial characteristics of firms in different countries. Kester (1986) and Wald (1999) compare the capital and ownership structures of firms in different countries and they find significant differences. Meric and Meric $(1989,1994)$ compare the financial characteristics of U.S. and Japanese manufacturing firms and they find significant differences. Meric at al. (2003) find significant differences between the financial characteristics of U.S. and Canadian manufacturing firms. Meric et al. (2002) find significant differences between the financial characteristics of U.S., EU, and Japanese manufacturing firms.

Some studies focus on certain industries. Meric et al. (1997a) compare the financial characteristics of U.S. and Japanese firms in the machinery and equipment manufacturing industry. Meric et al. (1997b) compare the financial 
characteristics of U.S. and Japanese Chemical firms. I. Meric et al. (2000) compare the financial characteristics of U.S. and Japanese Electronics firms.

There are three main objectives of studies that compare the financial characteristics of firms in different countries. The first objective is to provide information to corporate managers regarding the differences and similarities in corporate management practices in different countries. There is fierce global competition between countries to capture a greater market share in each other's local markets and in the world's other markets. Knowing how management practices differ between countries can provide valuable insights to corporate managers in managerial decision-making to become more competitive. The second objective is to provide information to global investors in terms of theliquidity, asset management, financial leverage (indebtedness), profitability, and risk characteristics of firms in different countries. A third objective of inter-country comparisons is to study the degree of integration between the economies of countries. Free competition, the removal of barriers to trade, and the free cross-border flow of capital increase economic integration between countries and firms in different countries tend to have similar financial characteristics with increased integration.

Meric et al. (2004) compare the financial characteristics of manufacturing firms within the EU. They conclude that, despite economic integration, significant differences exist between the financial characteristics of firms in EU countries. Meric et al. (2007) study the changes in the financial characteristics of EU firms during the 1990-2004 period. They conclude that differences between the financial characteristics of firms in different EU countries persist over time despite increased economic integration. In this paper, we make a contribution on this subject by using more recent data for September 2012. Our results should also capture the effect of the 2007-2009 global stock market crash on the financial characteristics of firms.

\section{Methodology and Data}

Multiple Discriminant Analysis (MDA) (see, e.g., Altman, 1968; Stevens, 1973; Belkaoui, 1978) and Multivariate Analysis of Variance-MANOVA (see, e.g., Hutchinson et al., 1988; Meric et al., 1991; Meric et al., 1997b) are two multivariate techniques most commonly used in previous studies to compare the financial characteristics of different groups of firms. In this study, we use the MANOVA technique to compare the financial characteristics of German and French manufacturing firms. Detailed information about the MANOVA methodology can be found in Marascuilo and Levin (1983) and Johnson and Wichern (2007).

Financial ratios are generally used in empirical studies to compare the financial characteristics of different groups of firms. We use the financial ratios presented in Table 1 to compare the financial characteristics of German and French firms. These are the financial ratios commonly used in financial analysis as measures of firm financial characteristics in comparisons (see: Brigham and Ehrhardt, 2010).

Our firm financial ratio data were obtained from the Research Insight/Global Vintage database in September 2012. Research Insight (COMPUSTAT) is the most widely used database in the U.S. for firm data. Global Vintage provides firm data for all world countries.

The manufacturing industries with SIC (Standard Industry Classification) four-digit codes between 2000-3999 are included in the study. Our research sample consists of 256 German and 191 French manufacturing firms with no missing financial data in the database.

\section{Empirical Findings}

Our MANOVA test results are presented in Table 2. The multivariate F-value test statistic (5.466) in the table indicates that the overall financial characteristics of German and French manufacturing firms are significantly different at the 1-percent level. Our univariate F-value test statistics in the table show that the financial characteristics of German and French manufacturing firms are significantly different in terms of most financial ratios.

\subsection{Liquidity}

Both liquidity ratios are significantly higher in German manufacturing firms than in French manufacturing firms at the 1-percent level. This indicates that German manufacturing firms are better able to meet their maturing obligations (i.e., German manufacturing firms have less technical insolvency risk) compared with French manufacturing firms.

\subsection{Asset Turnover}

German manufacturing firms have significantly higher asset turnover ratios (i.e., German firms have more efficient asset management) compared with French manufacturing firms. Accounts receivable turnover and total assets turnover ratios are significantly higher in German manufacturing firms than in French manufacturing firms at the 1-percent level. Fixed assets turnover ratio is significantly higher in German manufacturing firms than in French manufacturing firms 
at the 5-percent level. German and French inventory turnover ratios are more similar than the other turnover ratios. German mean inventory turnover ratio is higher than French mean inventory turnover ratio only at the 10-percent level of significance.

\subsection{Financial Leverage (Indebtedness)}

Common equity/total liabilities ratios are significantly higher in German manufacturing firms than in French manufacturing firms at the 5-percent level. This indicates that French manufacturing firms use significantly more debt financing (i.e., French manufacturing firms have significantly greater bankruptcy risk) compared with German manufacturing firms.

\subsection{Profitability}

Although German manufacturing firms have significantly greater efficiency in asset management compared with French manufacturing firms, the profitability ratios of German and French manufacturing firms are not significantly different at the conventional 5-percent level. This is because German manufacturing firms maintain significantly higher levels of less profitable liquid assets to lower their technical insolvency risk and they have significantly higher levels of equity to reduce bankruptcy risk. The mean return-on-assets ratio of German manufacturing firms is significantly higher than the mean return-on-assets ratio of French manufacturing firms at the 10-percent level. However, French manufacturing firms are able to boost their return-on-equity ratio by using more debt financing and greater financial leverage.

\subsection{Growth}

Annual sales growth rates of German and French manufacturing firms are not significantly different.

\section{Summary and Conclusions}

In this paper, we compare the financial characteristics of German and French manufacturing firms with the MANOVA (multivariate analysis of variance) technique. Germany and France are founding members of the European Union (EU). As a result of the use of a common currency (euro), free competition, removal of barriers to trade, and free cross-border flow of capital, one would expect German and French economies to be fully integrated and German and French firms to have similar financial characteristics. However, in this study, we find that many financial characteristics of German and French manufacturing firms are significantly different. Two previous studies also find that the financial characteristics of firms in different EU countries are significantly different and that the differences persist over time (see: Meric et al., 2004, 2007).

We find that economic integration may not make the financial characteristics of firms in different countries similar. Firms in different countries appear to preserve their distinct traditional ways of doing business despite economic integration (e.g., compared with French firms, German firms traditionally maintain higher levels of liquidity to lower their technical insolvency risk and they use less debt financing to lower their bankruptcy risk). Our findings in this study imply that it may require more than just economic integration to make firm characteristics in different countries to be similar. Perhaps it also requires cultural integration and change in traditions which may take considerably longer than economic integration.

We find that German manufacturing firms have significantly higher liquidity, asset management, and equity ratios compared with their French counterparts. The profitability and growth ratios of German and French manufacturing firms are not significantly different. It appears that French firms are using extensive debt financing and financial leverage to boost their return-on-equity ratios to the level in German competitors.

\section{References}

Altman, E. I. (1968). Financial ratios, discriminant analysis, and the prediction of corporate bankruptcy. Journal of Finance, 23(4): 589-609. http://dx.doi.org/10.1111/j.1540-6261.1968.tb00843.x

Beaver, W. H. (1968). Alternative financial ratios as predictors of failure. Accounting Review, 43(1): 113-122.

Belkaoui, A. (1978). Financial ratios as predictors of Canadian takeovers. Journal of Business Finance and Accounting, 5(1): 93-108. http://dx.doi.org/10.1111/j.1468-5957.1978.tb00177.x

Böcking, H., Gros, M., Wallek, C., \& Worret, D. (2012). Earnings management and enforcement of accounting standards - Evidence from Germany. SSRN Working Paper Series.

Brigham, M. C., \& Ehrhardt, E. F. (2010). Financial Management: Theory and Practice. $13^{\text {th }}$ ed. Mason, OH: South-Western Cengage Learning. 
Dambolena, I. G., \& Khoury, S. J. (1980). Ratio stability and corporate failure. Journal of Finance, 35(4): 1017-1026. http://dx.doi.org/10.1111/j.1540-6261.1980.tb03517.x

Deakin, E. B. (1972). A discriminant analysis of predictors of business failure. Journal of Accounting Research, 10(1): 167-179. http://dx.doi.org/10.2307/2490225

Edmister, R. O. (1972). An empirical test of financial ratio analysis for small business failure prediction. Journal of Financial and Quantitative Analysis, 7(2): 1477-1493. http://dx.doi.org/10.2307/2329929

European Union Website: http://www.Europa.eu/index_en.htm

Gultekin, M. N., Gultekin, N. B., \& Penati, A. (1989). Capital controls and international capital market segmentation: The evidence from the Japanese and American stock markets. Journal of Finance, 44(4): 849-870. http://dx.doi.org/10.1111/j.1540-6261.1989.tb02627.x

Hail, L., Leuz, C., \& Wysocki, P. (2010). Global accounting convergence and the potential adoption of IFRS by the U.S. (Part 1): Conceptual underpinnings and economic analysis. Accounting Horizons, 24(3): 355-394. http://dx.doi.org/10.2308/acch.2010.24.3.355

Hail, L., Leuz, C., \& Wysocki, P. (2010). Global accounting convergence and the potential adoption of IFRS by the U.S. (Part 2): Political factors and future scenarios for U.S. accounting standards. Accounting Horizons, 24(4): 567-588. http://dx.doi.org/10.2308/acch.2010.24.4.567

Hutchinson, P., Meric, I., \& Meric, G. (1988). The financial characteristics of small firms which achieve quotation on the UK unlisted securities market. Journal of Business Finance and Accounting, 15(1): 9-19. http://dx.doi.org/10.1111/j.1468-5957.1988.tb00116.x

Johnson, R. D., \& Wichern, D. W. (2007). Applied Multivariate Statistical Analysis. $6^{\text {th }}$ ed. Englewood Cliffs, NJ: Prentice Hall.

Kester, W. C. (1986). Capital and ownership structure: A comparison of United States and Japanese manufacturing firms. Financial Management, 15(1): 5-16. http://dx.doi.org/10.2307/3665273

La Porta, R., Lopez-de-Silanes, F., Shleifer, A., \& Vishny, R. (1998). Law and finance. Journal of Political Economy, 106 (December): 1113-1155. http://dx.doi.org/10.1086/250042

Marascuilo, L. A., \& Levin, J. R. (1983). Multivariate statistics in the social sciences. Monterey, California: Brooks/Cole Publishing Company.

Meric, G., Kyj, L., Welch, C., \& Meric, I. (2000). A comparison of the financial characteristics of Japanese Kieretsu-affiliated and independent firms. Multinational Business Review, 8(2): 26-30.

Meric, G., Leveen, S. S., \& Meric, I. (1991). The financial characteristics of commercial banks involved in interstate acquisitions. Financial Review, 26(1): 75-90. http://dx.doi.org/10.1111/j.1540-6288.1991.tb00370.x

Meric, G., \& Meric, I. (1992). A comparison of the financial characteristics of listed and unlisted companies. Mid-Western Journal of Business and Economics, 7(1): 19-31.

Meric, I., Gishlick, H. E., McCall, C. W., \& Meric, G. (2003). A comparison of the financial characteristics of U.S. and Canadian manufacturing firms. Midwestern Business and Economic Review, 31(1): 25-33.

Meric, I., Gishlick, H. E., Taga, L. S., \& Meric, G. (2007). The effects of economic integration on the financial characteristics of EU manufacturing firms: 1990-2004. Southwest Business and EconomicsJournal, 15(1): 1-8.

Meric, I., \& Meric, G. (1989). A comparison of the financial characteristics of U.S. and Japanese manufacturing firms. Financial Management-FM Letters-, 18(4): 9-10. http://dx.doi.org/10.2307/3665789

Meric, I., \& Meric, G. (1994). A comparison of the financial characteristics of United States and Japanese Manufacturing Firms. Global Finance Journal, 5(1): 205-218. http://dx.doi.org/10.1016/1044-0283(94)90004-3

Meric, I., Prober, L., Eichhorn, B., \& Meric, G. (2004). Integration and the financial characteristics of manufacturing firms in the European Union. American Business Review, 22(2): 88-96.

Meric, I., Romeo, G., Marmon, R., \& Meric, G. (1997a). A comparison of the financial characteristics of U.S. and Japanese machinery and equipment manufacturing firms. International Review of Economics and Business, 44(3): 695-704.

Meric, I., Ross, L., Weidman, S., \& Meric, G. (1997b). A comparison of the financial characteristics of U.S. and Japanese chemical firms. Multinational Business Review, 5(2): 23-27. 
Meric, I., S. Weidman, S., Welsh, C., \& Meric, G. (2002). A comparison of the financial characteristics of U.S., EU, and Japanese manufacturing firms. American Business Review, 20(2): 119-125.

Meric, I., Welsh, C., Pritchard, R., \& Meric, G. (2000). A comparison of the financial characteristics of U.S. and Japanese electronics firms. Asia Pacific Journal of Management, 17(1): 175-185. http://dx.doi.org/10.1023/A:1015497106392

Moyer, R. C. (1977). Forecasting financial failure: A re-examination. Financial Management, 6(1): 11-17. http://dx.doi.org/10.2307/3665489

Narktabtee, K., \& Patpanichchot, S. (2011). The impact of country-level vs. firm-level factors on the effectiveness of IFRS adoption: The case of European Union. The International Business \& Economics Research Journal, 10(10): 79-92.

Pownall, G., \& Wieczynska, M. (2012). Deviations from the mandatory adoption of IFRS in the European Union: Implementation, enforcement, incentives, and compliance. SSRN Working Paper Series.

Preiato, J., Brown, P., \& Tarca, A. (2012). Mandatory adoption of IFRS and analysts' forecasts: How much does enforcement matter? SSRN Working Paper Series.

Rege, U. P. (1984). Accounting ratios to locate take-over targets. Journal of Business Finance and Accounting, 11(3): 301-311. http://dx.doi.org/10.1111/j.1468-5957.1984.tb00751.x

Stevens, D. L. (1973). Financial characteristics of merged firms: A multivariate analysis. Journal of Financial and Quantitative Analysis, 8(2): 149-158. http://dx.doi.org/10.2307/2330007

Stulz, R. M. (1981). On the effects of barriers to international investment. Journal of Finance, 36(4): 923-934. http://dx.doi.org/10.1111/j.1540-6261.1981.tb04893.x

Wald, J. K. (1999). How firm characteristics affect capital structure: An international comparison. Journal of Financial Research, 22(2): 161-187.

Wikipedia Website: http://en.wikipedia.org/wiki/EuropeanUnion

Table 1. Financial Ratios Used in the Study as Measures of Firm Financial Characteristics

\begin{tabular}{|l|l|}
\hline Financial Ratio Name & Financial Ratio Definition \\
\hline Liquidity & $\begin{array}{l}\text { Current Assets / Current Liabilities } \\
\text { (Current Assets - Inventories) / Current Liabilities }\end{array}$ \\
\hline Quick Ratio (QR & Asset Management (Turnover) Ratios \\
\hline Accounts Receivable Turnover (ART) & Sales / Accounts Receivable \\
Inventory Turnover (INT) & Sales / Inventory \\
Fixed Assets Turnover (FAT) & Sales / Net Fixed Assets \\
Total Assets Turnover (TAT) & Sales / Total Assets \\
\hline Financial Leverage (Indebtedness) & Common Equity/Total Liabilities \\
\hline Equity Ratio (ER) & Net Income / Sales \\
\hline Profitability & Operating Income / Sales \\
\hline Net Profit Margin (NPM) & Net Income / Total Assets \\
Operating Profit Margin (OPM) & Net Income / Common Equity \\
Return on Assets (ROA) & Average for the Last Three Years \\
Return on Equity (ROE) & Growth
\end{tabular}

The financial ratios listed in this table were used in the MANOVA tests. 
Table 2. MANOVA Statistics

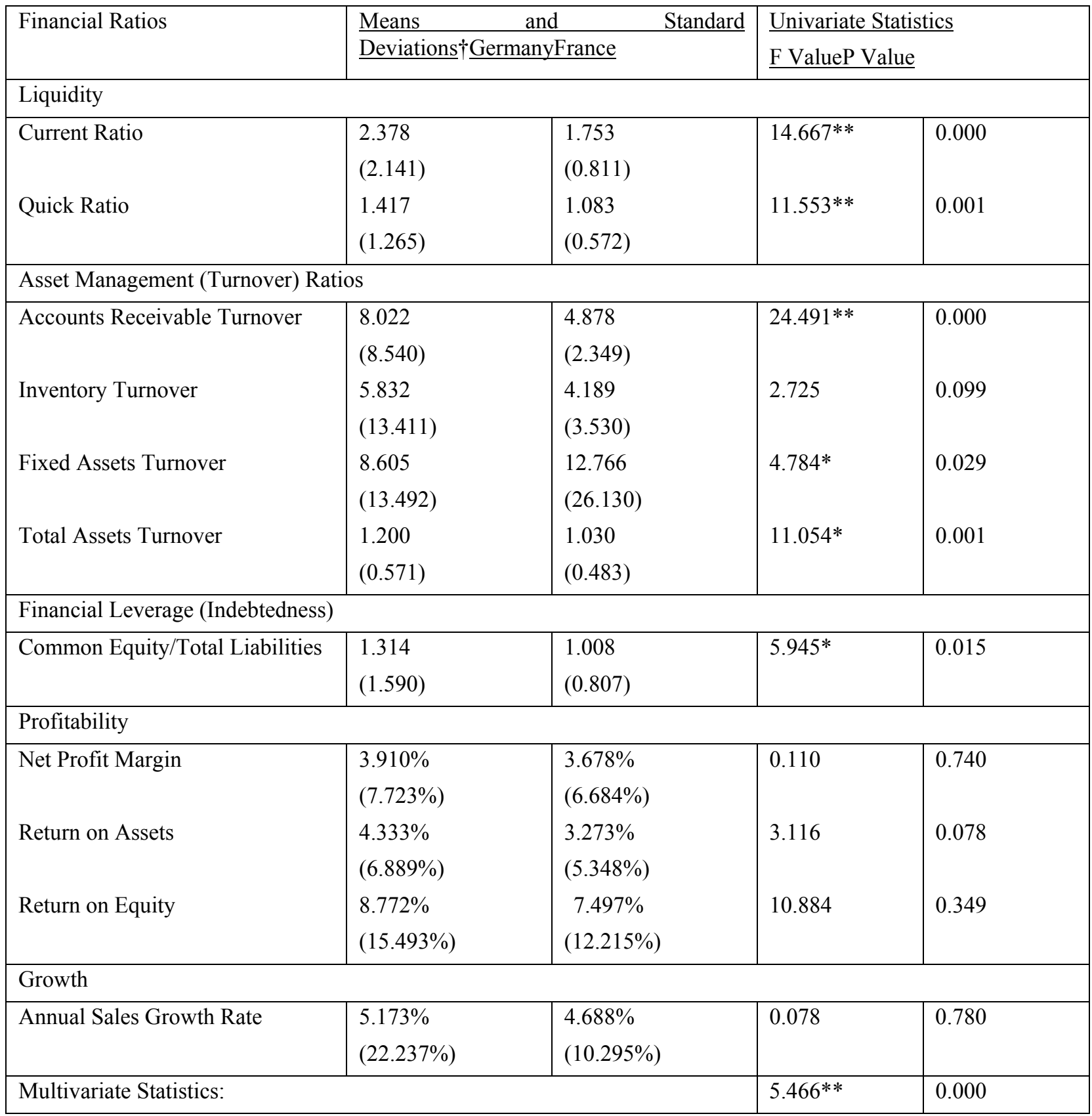

$\dagger$ The figures in parentheses are the standard deviations.

**, * indicate that the difference is significant at the 1-percent and 5-percent levels, respectively. 